\title{
BANK ACCOUNTING PRINCIPLES:
} A PROGRESS REPORT

\author{
EDWARD T. SHIPLEY*
}

For many years the commercial banks throughout the country have worked with the accounting profession in attempts to obtain complete disclosure of the financial condition of business and industry as it affects the extension of bank credit. At times, representatives of the banking group have been publicly critical of the certifications used in, and omissions from, industry's financial reports. ${ }^{1}$ Despite this, few segments of the economy have been more secretive concerning their own financial condition than the commercial banks. Employing some extremely conservative accounting practices originally designed to provide an additional measure of protection for their depositors, the banks have been accused of practicing "concealment accounting"2 insofar as public reporting is concerned. Until recently, few bank shareholders were well enough informed through banks' financial disclosure to appraise adequately the quality of their investment in terms of either realistic book values or earnings per share.

Recent developments have begun to alter banks' attitudes on the subject of financial disclosure in the interests of investors, and it is the purpose of this article to review the progress being made in this direction and in developing and implementing useful and uniform bank accounting principles. The developments to be considered here are in many respects related to the larger quest of the accounting profession for increased "uniformity" and "comparability" of financial statements-that is, a narrowing of the range of alternative accounting treatments available in particular circumstances. ${ }^{3}$ But banking's accounting problems are often distinguishable from those of other industries, and the institutional character of banking is such that problems must be faced and solved on an industry basis. For one thing, bank accounting principles have been less clearly defined than the principles employed by businesses of other kinds, and therefore require special attention. Furthermore, bank accounting must reflect the needs not only of investors but also of bank management, depositors, and the bank supervisory agencies; these special uses of accounting data further suggest

- Comptroller, Wachovia Bank and Trust Company, Winston-Salem, N.C. Chairman, Accounting Principles Committee, American Bankers Association; President, The Association for Bank Audit, Control, and Operations (NABAC).

${ }^{1}$ E.g., Address by J. Howard Laeri, Vice Chairman of First National City Bank, Before the Credit Policy Committee of the American Bankers Association, Feb. 1, r966, reported in N.Y. Times, Feb. 2, 1966, at 43, col. 2, and in J. Accountancy, March 1966, at 57. For a reply to Laeri's remarks, see Editorial, A Banker Looks at Auditors, id. at 31.

${ }^{2}$ Address by J. L. Robertson, Vice Chairman of the Board of Governors of the Federal Reserve System, The Association for Bank Audit, Control, and Operations (NABAC) National Convention, Sept. 1965.

${ }^{8}$ See, e.g., Symposium-Uniformity in Financial Accounting, 30 Law \& Contemp. Prob. 621 (I965). 
the uniqueness of the accounting problems confronted in banking. Lastly, by assigning, in 1964, supervisory authority over bank securities registration to the banking agencies rather than to the SEC, Congress appears to have recognized the need of banks for specially tailored disclosure requirements and to have strengthened the case for severing banks' accounting problems from those of industry generally.

\section{Some Background on Bank Accounting}

One explanation for bank accounting's slow progress toward achieving meaningful disclosure by current investors' standards is the conservatism with which investors viewed bank stocks until quite recently. After the depression of the 1930 , investors treated bank stocks as in a class with bonds, preferred stocks, and mortgages and were therefore concerned primarily with the book or other liquidation value of shares. Interest focused on the balance sheet, which was usually the only statement made available, and market price fluctuated around liquidation value. The close government supervision of balance sheet preparation and the conservatism of the accounting principles that were followed tended to invite investor confidence in the balance sheets on which they were relying, which was probably all right as long as security was the sole desideratum. It was sometime in the I950s, at about the same time that banks began to display greater competitiveness and interest in growth and expansion, that investors began to consider bank stocks as alternatives to industrial common stocks. An immediate need for meaningful income statements thus arose, and investors and financial analysts found themselves supplied with inadequate information in a form that precluded safe comparisons of one bank with another or with industrial corporations.

Prior to the Securities Acts Amendments of $1964,{ }^{5}$ not a great deal was done to provide bank shareholders and the investment community with needed information. ${ }^{b}$ Some larger banks had begun to publish income statements, but most banks limited their disclosure of their financial affairs to the dissemination of the reports of condition required by the various supervisory authorities. ${ }^{7}$ These reports, in forms prescribed by the Comptroller of the Currency, ${ }^{8}$ the Federal Reserve Board, the Federal

\footnotetext{
'See Cates, A Stock Analyst Looks at Uniform Bank Accounting, Audrtgram, August 1965, at 12.

${ }^{5}$ Pub. L. No. $88-467,78$ Stat. 565 (codified in scattered sections of 15 U.S.C.).

${ }^{8}$ See generally on the pre-existing regulatory situation and the practices of banks in supplying financial data, SEC, Report of Special Study of Securities Markets, H.R. Doc. No. 95, 88th Cong., ist Sess., pt. 3, at 36-39 (1963) [hereinafter cited as Specias Study Report]; Staff of Subcomm. on Domestic Finance, House Comm. on Banking and Currencx, 88th Cong., 2d Sess., The Market For Bank Stock I8-25 (Subcomm. Print I964); E. Lerner, Staff of Subcomm. on Domestic Finance, House Comm. on Banking and Currency, 88th Cong., 2d Sess., Commercial Bank Reportino Practices to Stockholders (Subcomm. Print 1964).

"A good survey of the requirements of bank supervisors and the problems of analyzing the limited data disclosed is R. D. Kennedy \& S. Y. McMulien, Financial Statements: Form, Analysis, \& InterPRETATION 68r-7ig (4th ed. Ig62).

${ }^{8}$ In 1962 , the Comptroller, apparently in an attempt to head off legislation extending the federal securi-
} 
Deposit Insurance Corporation (FDIC), or state supervisory agencies, were largely identical in format. They were filed quarterly with the agencies but were typically published, as required, twice a year. 'The similarity in the statements' appearance belied the lack of uniformity in the accounting principles employed in their preparation. Statements of one bank could not be safely compared with those of another, and the prescribed forms made no provision for footnotes to explicate the figures and the accounting techniques followed in arriving at them. Statements of financial condition did not reveal earnings except as they might perhaps be deducible by comparison of surplus and undivided profit figures with the same accounts disclosed in earlier statements; comparative figures, showing changes from one statement to the next, were never required and seldom provided. While most supervisory authorities did require the fling of annual reports of earnings and dividends, these were unavailable to the public.

The accounting principles employed in assembling statements of condition pursuant to supervisory requirements were selected out of a maximum regard for accounting conservatism, ${ }^{9}$ and the resulting financial statements were rendered more obscure on that account. Conservatism was consciously employed in the interest of providing the maximum protection for depositors, whose confidence was deemed both essential and precarious and whose well-being was the sole object of the bank supervisors. Little attention was paid to the needs of bank shareholders and potential investors; both as a cause and as an effect of the low visibility of bank earning power, investor disinterest in bank stocks as growth investments prevailed for a long time.

Instances of the long-established conservatism in bank financial reporting are discussed at length in the rest of this article. It suffices to note here, as examples of the obscurantism practiced in the interest of depositors, the quick writing off, or writing down to nominal values, of the bank's fixed assets and the creation of reserves not revealed on the balance sheet. These particular practices even made comparison of the equity portion of the balance sheet from year to year unhelpful as a means of evaluating earning power since neither retained earnings nor the impact of inordinate gains or losses in the bond account or losses in the loan account could be determined.

While the slow progress in bank accounting is most directly attributable to supervisors' and bankers' primary concern with the safety of deposits and the preservation of depositor confidence, there is reason to believe that the emerging new emphasis on accounting principles to be employed in reporting to shareholders will sooner or later change banks' practices in accounting to depositors and supervisory

ties laws to banks, adopted requirements for annual reports to shareholders of national banks and attempted to provide other investor protections analogous to those in the securities laws; the required annul report was to contain comparative balance sheets and income statements and a reconciliation of the capital account. 27 Fed. Reg. 128 I I (I962). See Special Study Report, pt. 3, at 39.

' See H. W. Bevis, Corporate Financial Reporting in a Competitive Economy 86 (1965): "Authorities supervising banks ... have historically tended to require or permit the affected corporations to use those accounting practices which emphasize liquidity." 
agencies. According to one writer, "the question is whether banks, supervisors, and the banking public are not now sophisticated enough to deal with banking facts as they are, without the psychological cushioning that certain time-honored practices seem to provide."10 Certainly the presence of deposit insurance greatly diminishes the need to tailor financial disclosure to depositors' special requirements. Both for this reason and because the new accounting principles being developed portray more accurately the bank's true condition, the trends we trace below may ultimately extend to all bank accounting. Statements produced in accordance with the accounting principles being evolved should be more useful to all concerned with any bank, either as a money-making business or as a depository of funds.

\section{II}

\section{Effects of the Securities Acts Amendments of rg64}

\section{A. Banks and the Securities Laws}

Banks were exempted from the disclosure requirements of the Securities Act of I933, ${ }^{11}$ probably because of a general belief that bank supervision would protect the various interests of the public, including those of shareholders. ${ }^{12}$ The Securities Exchange Act of 1934 contained no such exemption for banks from the requirements for periodic reporting of financial information to the Securities and Exchange Commission (for insertion in public files, which are regularly consulted by the financial community). Nevertheless, the SEC promptly exempted banks from the reporting and other requirements as a "temporary" measure. ${ }^{13}$ Since only bank securities listed on securities exchanges would be subject to the 1934 act requirements anyway and since bank stocks were traded almost exclusively over the counter, ${ }^{14}$ there was never any particular reason for the SEC to set aside this exemption, and it remained in effect up until I964. Thus, before the 1964 amendments, the securities laws did not affect banks at all in their relations with investors in bank stocks except as certain antifraud provisions applied. ${ }^{15}$

The Special Study of Securities Markets in 1963 proposed the extension of the I934 act's reporting, proxy, and insider-trading rules to certain unlisted securities, and specifically recommended that no exception be made for banks. ${ }^{16}$ The ensuing legisla-

\footnotetext{
${ }^{10}$ Hexter, Disclosttre for State Banks, Audrtgram, June 1965, at $4,46$.

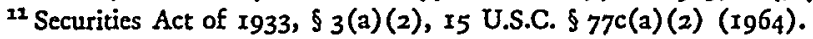

${ }^{22}$ See Special Study Report, pt. 3, at 36. See generally Comment, Banks and the Securities Act of 1933, 52 VA. L. REv. II7 (I966), reprinted in 84 BANKING L.J. 95 (1967), arguing that ( 1 ) there was in 1933 no basis for concluding that bank supervisors were adequately looking out for sharcholders' interests, and (2) the 1933 act exemption is inappropriate today as well.

${ }^{13}$ I7 C.F.R. \$240.12a-I (1964).

${ }^{14}$ Only five banks had securities listed on registered national securities exchanges in 1963. Special Study Report, pt. 3, at 36 . Each of these enjoyed a special exemption from Rule 12a-1. 2 L. Loss, Securities Regulation 800 (2d ed. Ig6r).

${ }^{15}$ Securities Act of 1933 , $\$ \S 12(2)$, I7, 15 U.S.C. $\$ \$ 77 l(2)$, 779 (1964); Securities Exchange Act of 1934, § ro, I5 U.S.C. $\$ 78$ j (1964).

io Special Study Report, pt. 3, at 35-39.
} 
tion in 1964 made a concession to banks only by vesting the new regulatory authority over each federally insured bank in the respective federal agency responsible for supervising the bank generally. ${ }^{17}$ Depriving the SEC of its accustomed authority has resulted in the development of highly specialized accounting requirements for the banking industry. Dividing the new regulatory authority three ways has produced some differences in the accounting practices and principles prescribed for the various classes of banks. The recent publication by the Comptroller of more detailed accounting regulations for national banks ${ }^{18}$ has narrowed the divergencies substantially, but some still remain and are mentioned below.

The Securities Acts Amendments extended the 1934 act's reporting, proxy, and insider-trading requirements to corporations having over $\$ \mathrm{I}$ million in assets and 500 or more shareholders. ${ }^{19}$ These numerical tests greatly limit the law's application to commercial banks and hence weaken the statutory sanction for the disclosure sought in the banking industry. Thus, the new law extends coverage to only about 600 of the nation's nearly I4,000 banks, although the securities of these banks are held by some $1,600,000$ shareholders and represent thirty-six per cent of the outstanding securities of those banks whose securities have evoked some trading interest. ${ }^{20}$ In addition, the Comptroller's regulations concerning annual reports to shareholders purport to cover all national banks (some 4,800 institutions), not merely those newly subject to the 1934 act. $^{21}$ The Federal Reserve and the FDIC have not gone so far..2 It is widely believed, however, that smaller banks will gradually be influenced to adopt the accounting principles and some of the reporting practices prescribed by the federal agencies. Nevertheless, the chances for achieving greater accounting uniformity by voluntary adherence to regulatory prescriptions would probably be enhanced if the three federal banking agencies could agree on a common regulation. To date this has not been done.

The three banking agencies set out in two different directions to implement their new authority under the 1964 amendments. The Federal Reserve immediately joined forces with the FDIC and promptly produced substantially identical regulations. ${ }^{23}$ (The Federal Reserve's version is called Regulation $F$, to

\footnotetext{
${ }^{17} 15$ U.S.C. $\$ 78 l$ (i) $(1964)$. Thus, the Comptroller is responsible for national banks, the Federal Reserve for state member banks, and the FDIC for insured state nonmember banks. Uninsured nonmember banks would be subject to the SEC's jurisdiction; however, Chairman Cary estimated in 1963 that only four banks meeting the jurisdictional requirements would fall in this last category. S. REP. No. 379, 88th Cong., Ist Sess. 51 (1963) (letter from Chairman William L. Cary to Senator A. Willis Robertson).

${ }^{18}$ Comptroller of the Currency Reg. $\$ \$ 18.1-.7,32$ Fed. Reg. 707I (I967).

${ }^{10} 15$ U.S.C. $\$ 78 l(\mathrm{~g})$ (1964).

${ }^{20}$ S. ReP. No. 379, 88th Cong., Ist Sess. 52 ( 1963 ) (letter from Chairman William L. Cary to Senator A. Willis Robertson).

${ }^{21}$ Comptroller of the Currency Reg. $\$$ ro.I, 32 Fed. Reg. 7070 (1967).

${ }^{22}$ See Bank Disclosure: Another Step Forward, BANK Srock Q., March 1967, at 15, for the view that "there is no valid reason for any bank, regardless of size, to be exempt from disclosure provisions."

${ }^{28} 12$ C.F.R. $\$ \$ 206.1-.7$ I, 335.I-.7I (Supp. 1966).
} 
which we shall refer hereafter.) These regulations required, among other things, that statements disseminated by a bank in connection with its annual stockholders' meeting should be a "fair presentation" when "considered as a whole ... in the light of the financial statements of the bank filed or to be filed" with the agency, and prescribed in considerable detail the matter to be contained in the latter statements. ${ }^{24}$ The Comptroller of the Currency, on the other hand, confined himself to the continuation of his pre-existing requirement that annual reports be provided to shareholders, adding a provision to the effect that filing of a copy of the annual report with him would constitute registration under the Exchange Act. ${ }^{25}$ The Comptroller's regulations initially included no accounting rules or requirements whatsoever and consequently left national banks free to follow practices inconsistent not only with each other but also with state banks subject to Federal Reserve and FDIC regulation. ${ }^{26}$

In 1967 , the Comptroller has finally promulgated some brief but effective accounting regulations that considerably narrow the gap between his requirements and those of Regulation F. ${ }^{27}$ Differences persist, however, most particularly in several of the areas discussed later in this article. Moreover, the Comptroller's rules omit to prescribe the treatment of certain items, such as long-term lease commitments, on which Regulation $F$ takes an express position. ${ }^{28}$ As to all of these matters, it would be desirable if the Comptroller's regulations would conform to Regulation $F$, since the Regulation F treatment is generally preferable from an accounting standpoint. On the other hand, the Comptroller's regulations represent a salutary advance over Regulation F in prescribing a precise format in which the balance sheet, earnings statement, and reconciliation of reserves must be presented to shareholders; Regulation F's rules have governed the form of shareholder reports only indirectly by requiring that they be a "fair presentation" of the data supplied to the Board. The Comptroller's prescribed format should do much toward producing uniformity and comparability among the banks complying with it.

\section{B. The Issue of Certification and Independent Audit ${ }^{20}$}

The early drafts of Regulation $\mathrm{F}$ included a requirement that the financial statements included in a bank's annual report to shareholders be certified by an inde-

${ }^{24}$ I2 C.F.R. \$206.5, 206.103 (Supp. 1966).

${ }^{25} 29$ Fed. Reg. 12300 (I964).

${ }^{20}$ The conflict which thus developed between the Federal Reserve and the Comptroller was typical of a series of conflicting legal interpretations adopted by the agencies in recent years. These conflicts have contributed to creating a competitive disadvantage for state banks. See, e.g., Symposium-Banking Regulation, 3I LAw \& Contemp. ProB. 635 (1966).

${ }^{27}$ Comptroller of the Currency Reg. $\$ \$ 8 . x-.7,32$ Fed. Reg. 7071 (1967).

${ }^{28}$ The Federal Reserve's position on long-term lease commitments appears in 12 C.F.R. $\$ 206.7(c)(8)$ (Supp. I966).

${ }^{29}$ For recent and thorough discussions, see Larsen, The Controversy Over Independent Audits for Banks, J. Accountancy, May 1967, at 42; Walker \& Mellilo, What the New Regulations Mean to Banks, Price Waterhouse Rev., Spring 1965, at 4, 6-10; Bettauer, Should Banks Have Independent Audits?, Price Waterhouse Rev., Winter 1965, at 14. 
pendent public accountant. Such a certification would, of course, entail an audit "in accordance with generally accepted auditing standards" and the expression of an opinion as to the conformity of the statements with "generally accepted accounting principles." An audit meeting such standards and supporting such an opinion would be an expensive undertaking. A bank having a set of strong internal controls could be audited more easily than one not having adequate internal auditing procedures, but the evaluation of the controls employed and the making of necessary tests to verify their effectiveness is nevertheless difficult and to a considerable extent duplicative. $^{30}$ Moreover, the regulatory agencies' bank examiners perform some of the same functions that an auditor would perform. ${ }^{31}$ Because the internal audit staffs of the large banks to be covered by Regulation $F$ were deemed largely adequate, at least when backstopped by regular governmental supervision, the Federal Reserve dropped the requirement of independent certification in the final version of Regulation $\mathrm{F}^{32}$ The Comptroller has imposed no certification requirement.

The question of the need for independent audit of bank financial statements is still very much alive, however. Occasional bills in Congress, ${ }^{33}$ representatives of the accounting profession ${ }^{34}$ and of the investment community, ${ }^{35}$ and some bank regulators ${ }^{36}$ have expressed the view that independent audits of banks should be required. The debate is likely to continue, but it is believed by this writer that certification will usually not be worth what it costs until such time as bank accounting principles are better defined than they are at the moment. A certification that statements have been prepared "in accordance with generally accepted accounting principles" is of little value if such principles have not been agreed upon in some measure; indeed, the certification may render the statements more misleading by seeming to warrant their comparability with financial statements of other banks or even with those of firms in other industries.

A number of banks throughout the country believe that their responsibility to their shareholders and the investing public requires them to employ independent accounting firms to certify the financial statements in their annual reports. Despite these cer-

\footnotetext{
${ }^{30}$ Some of the larger banks maintaining substantial internal audit departments have employed outside accounting firms to evaluate the scope and effectiveness of the internal audit program. Such reviews cost less than a complete audit of the bank, yet contribute substantially to the improvement of bank accounting.

${ }^{32}$ The differences outnumber the similarities, however, and should be stressed.

${ }^{32}$ I2 C.F.R. $\$ 206.7$ (b) (Supp. I966). Unlike the Comptroller's regulations, Regulation F does require an opinion as to the financial statements by the bank's principal accounting officer and auditor if an independent accountant's certification is not obtained. I2 C.F.R. $\$ 206.2$ (dd) (Supp. I966). The accountant's opinion, if supplied, however, must be more comprehensive than that required of the bank's own accounting officer. I2 C.F.R. $\$ \S 206.7$ (b) (2), 206.7(b)(3)(ii) (Supp. I966). See Walker \& Mellilo, supra note 29 , at 6-7.

${ }^{33}$ E.g., H.R. 40, 89th Cong., Ist Sess. (1965); H.R. 123, 89th Cong., Ist Sess. (1965).

" E.g., Letter from Committee on Bank Accounting and Auditing, AICPA, to Board of Governors of the Federal Reserve System, Nov. 9, I964, reprinted in J. Accountancy, Dec. I964, at 59.

${ }^{35}$ See, e.g., Cony, Bank-Report Fracas, Wall Street Journal, June 4, 1965, at I, col. I.

${ }^{30}$ E.g., Hearings on the Crown Savings Bank Failutre Before the Subcomm. on Domestic Finance of the House Comm. on Banking and Currency, 89th Cong., Ist Sess. 580-83, 585 (1965) (testimony of K. A. Randall, Chairman, Federal Deposit Insurance Corporation).
} 
tifications, however, there persists a lack of uniformity in the accounting practices employed. While the CPAs' reports are objective, they have adopted varying treatments of such important items as the reserve for bad debts and the gains or losses on securities transactions. ${ }^{37}$ Clearly, the desired accounting results cannot be achieved simply by turning each bank's problems over to a CPA.

Surprisingly, the use of independent accountants has not been confined to large banks alone. Small banks which are unable to support a substantial internal audit staff are more and more frequently utilizing the services of outside auditors to meet their needs. This is a healthy trend, and it is the opinion of this writer that, as the need for sound audit programs is more widely recognized, the use of independent accounting firms will spread more rapidly among smaller banks than among large ones.

\section{III}

\section{Achieving UNIFormity: Specific IssUes Resolved}

In the development of Regulation F, the Federal Reserve Board and the FDIC recognized the need to establish uniform accounting practices to support the financial statements to be required if they were to achieve any significant degree of uniformity and comparability. They sought the opinions of the American Institute of Certified Public Accountants (AICPA), the Financial Analysts Federation, the Association for Bank Audit, Control, and Operation (known as "NABAC"), the American Bankers Association, and the New York Clearing House Association.

As of this writing, the AICPA has not developed or agreed upon "generally accepted accounting principles for banks," although a draft booklet bearing that title has been circulated by its Committee on Bank Accounting and Auditing. Accountants and bankers are very much at work on the problems, and some broad agreement may soon be reached. For the moment, however, the Federal Reserve's Regulation F provides the most definitive guide to bank accounting principles. The ensuing discussion of some of the specific issues relies principally on Regulation $F$ as the authority for calling the questions settled. Accountants and some bankers may not be satisfied on some of the points, and on several issues, as is indicated, the Comptroller has just taken a slightly divergent position or has taken no position at all. Never-

\footnotetext{
${ }^{37}$ Some question might be raised as to how accountants have been able to give "clean" opinions on financial statements incorporating unusual accounting techniques peculiar to banks. One writer suggests that it has been done "presumably on the theory that the results of these practices did not preclude a 'fair presentation' and in a spirit of temporary acceptance of 'special-interest' accounting for banks." Doherty, The Banker and the CPA: Some Matters of Mutual Interest, ARTHUr Young J., Spring 1967, at 2, 8. The accountant's problem is similar to that encountered in other regulated industries where regulators insist on accounting treatments not deemed "generally accepted" by the certifying accountant. See Price, Walker \& Spacek, Accounting Uniformity in the Regulated Industries, 30 LAw \& ConTEMP. ProB. 824 (1965).
} 
theless, Regulation F remains our chief and most comprehensive authority on bank accounting. ${ }^{38}$

\section{A. Accrual Accounting}

Despite the recognition that accrual accounting has been accepted by most business ventures of any consequence, it has not been uniformly adopted by commercial banks. ${ }^{39}$ Accrual accounting, which is the only method giving recognition to revenues and expenses in the period to which they relate, rather than in the period when they were actually received or paid, provides the only true basis for adequate financial reporting. It was the consensus of all of the interested parties presenting opinions to the Federal Reserve Board that Regulation F should incorporate the requirement that all financial reports be prepared on the basis of accrual accounting; an exception was made with regard to trust fees and commissions because of their lack of predictability and because of a lack of materiality. As a consequence the Federal Reserve Board in its general instruction covering the preparation of financial statements included the following: ${ }^{40}$

\section{Accrual Accounting.}

Financial statements shall generally be prepared on the basis of accrual accounting whereby all revenues and all expenses shall be recognized during the period earned or incurred regardless of the time received or paid, with certain exceptions: (a) income on securities in the trading account and (b) where the results would be only insignificantly different on a cash basis, or where accrual is not feasible....

While the Comptroller's new regulations apply to all national banks, the requirement of accrual accounting is extended only to the larger banks. ${ }^{41}$ Thus, banks with assets of less than \$roo million need not comply immediately, and banks having less than $\$ 25$ million in resources are not to be subjected to the broad accrual accounting requirement. ${ }^{42}$ However, all national banks must, for fiscal years beginning in Ig68 and thereafter, either handle income from installment loans and the related taxes on an accrual basis or, alternatively, provide a footnote indicating the amount of unearned discount on installment loans that is being carried in the capital accounts. As under Regulation F, trust department income may be reported on a cash basis.

\footnotetext{
${ }^{38}$ Other authoritative, though unofficial, sources include Chaut, Progress Report of the Bank SubCommittee of the Corporate Information Committee, Financial. Analysts J., Nov.-Dec. I966, at II; Committee on Bank Accounting and Auditing, AICPA, Bank Accounting \& Financial Reporting Practices and Their Relationship to Generaliy Accepted Accounting Principles (ig66), published only to serve as a basis for discussion among interested parties in the banking field; NABAC, SEcurutres Accounting (Accounting Bulletin No. I, rev. I966); NABAC, LoAn Loss ANd Related Reserve Accounting (Accounting Bulletin No. 3, I966); NABAC, Accounting for Bank Premises, Equipment aNd Other Real Estate OwNed (Accounting Bulletin No. 4, 1966); E. LerNer, supra note 6.

${ }^{30}$ See Austin, A Survey of Accounting and Reporting Practices, Auditgram, Feb. I964, at 4, 5.

${ }^{10}$ I2 C.F.R. $\$ 206.7$ I (Supp. 1966) (Form F-9).

" Comptroller of the Currency Reg. $\$$ I8.3, 32 Fed. Reg. 7071 (I967).

"Austin, supra note 39, discloses the results of a survey indicating that the great majority of banks having less than $\$ 25$ million in deposits employ the cash method or a combination of cash and accrual accounting.
} 


\section{B. Accretion of Discount}

A second item of controversy in the development of Regulation $F$ was the matter of the accretion of discount. It was recognized that income on bonds purchased at a discount, where the discount is not amortized, is reflected at the coupon rate rather than the yield basis and may therefore materially understate revenues.

The treatment of discount on securities had varied widely between banks, as had the treatment of bond premium. Among the prevalent practices for the treatment of bond premium was the write-off of such premiums to the undivided profits account at the date of acquisition. Other banks amortized the premium against operating earnings to the maturity of the bond acquired, while a variation on this practice included the amortization of such premiums to the call date of the security. Prior to I955, few if any banks accreted the discount on bonds purchased below par. Normally, such securities were carried at cost on the books of the bank with the full capital gains being taken at the maturity of the security. There seems to be little rationale for this difference in treatment of premium and discount, but the results of the varying methods of treatment had a direct impact on the comparability of earnings statements and balance sheets.

The Internal Revenue Code allows the amortization of bond premiums for tax purposes, ${ }^{43}$ but, as is frequently the case, tax accounting methods are not necessarily reflected on the books of the bank, such tax adjustments being made through memo. randa records. In the case of a bank which charged the premium directly to undivided profits at the date of acquisition, the bonds were shown on the balance sheet at par while the earnings statement reflected the full coupon income. For those banks that amortized such premiums, the bonds were carried at the unamortized value, and the amortized premium offset to a degree the coupon income in the earnings statement. If the amortization were to an earlier call date, the amount of such amortization would be increased and the coupon rate decreased commensurately. Here again, the majority opinion favored the accrual of such discounts in order that the operating statements of the bank would reflect the true yield on securities acquired rather than the coupon rate. As a consequence, the instructions relating to the required financial statements under Regulation $\mathrm{F}$ include the following: ${ }^{44}$

2. Investment securities....

(b) Book value ... shall be cost adjusted for amortization of premium and, at the option of the bank, for accretion of discount. If the reporting bank does not accrete discount, the amount that could have been accreted shall be set forth in a footnote.

The option on accretion of discount and the last sentence were included as a result of representations made by various banks to the supervisory authorities as to the cost involved in the bookkeeping functions necessary to meet a hard and fast requirement.

\footnotetext{
1s INT. REv. CoDE of I954, § I7I.

14 12 C.F.R. $\$ 206.7$ I (Supp. 1966) (Form F-9A).
} 
The Comptroller's regulations take a somewhat different approach to this problem, leaving accretion of discount in the bank's discretion but requiring disclosure only where there is an actual accrual and the amount is five per cent or more of bond income. ${ }^{45}$ Thus, national banks need not report in any form the effects of purchasing securities at a discount, while banks subject to Federal Reserve or FDIC regulation must disclose all relevant information in the statements or in a footnote thereto.

\section{Valuation of Fixed Assets}

The valuation of fixed assets is another area where bank accounting has differed materially from generally accepted accounting principles. In the interest of conservatism, investments in banking premises have in many instances been written down to nominal values, or substantial reserves have been allocated against values in excess of the depreciation allowances under the Internal Revenue regulations. Similarly, the items of furniture, fixtures, and equipment have been charged to operating expense as opposed to their capitalization and their true worth thereby extracted from the balance sheet.

In establishing the reporting requirements, the Federal Reserve and the FDIC were in agreement that the cost basis was necessary to any reliable objective and consistent financial recording and reporting. Here again, it was the consensus that, in the interests of sound accounting practice, the traditional write-down of assets should be abandoned and the assets reported at cost less accrued depreciation. Similar treatment was to be afforded leasehold improvements. These new practices reflect the application of accounting principles long "generally accepted" by the accounting profession.

During the course of discussions, it was represented to the supervisory agencies that the restoration of values written down in prior years would be extremely difficult to accomplish because of the length of time during which the practice had been in vogue and because many of the properties had been acquired through merger and the write-downs had occurred while the properties were held by a predecessor bank. For these reasons, Regulation $\mathrm{F}$ included a modifying instruction: ${ }^{46}$

5. Bank premises and equipment....

(b) All fixed assets acquired subsequent to December 3I, I959, shall be stated at cost less accumulated depreciation or amortization.

(c) All fixed assets acquired prior to January $I$, I960, that are not presently accounted for by the bank on the basis of cost less accumulated depreciation or amortization, may be stated at book value. Any such assets that are still in use and would not have been fully depreciated on a straight-line method of accounting for depreciation if the bank had recorded depreciation on such basis shall be described brielly in a footnote, together with an explanation of the accounting that was used with respect to such assets.

\footnotetext{
${ }^{15}$ Comptroller of the Currency Reg. $\S 18.5$ (b), 32 Fed. Reg. 707I (1967).

10 I2 C.F.R. \& 206.7I (Supp. I966) (Form F-9A).
} 
This was undoubtedly a compromise with objective reporting, but, based upon representations made to the regulatory authorities, failure to reach such a compromise would have created serious problems in the determination of cost less allowable depreciation.

The Comptroller's new regulations provide that "all fixed assets acquired subsequent to June 30,1967 , shall be stated at cost less accumulated depreciation or amortization." ${ }^{477}$ The cut-off date might have been fixed earlier, it would seem, but the principle of allocating the cost of fixed assets over the time during which they are employed, a principle essential to any meaningful system of financial reporting, has at least been recognized and established for the future. As the effects of the old accounting treatment dissipate with the passage of time, greater comparability will gradually emerge. Still, the agencies might have done more to hasten the day when bank fixed assets would all be accounted for alike.

\section{Stock Dividends Issued}

A fourth area of controversy in bank accounting concerns the proper treatment of stock dividends issued. The proposal has been made that stock dividends should be capitalized at the market value of such shares at the date of issue rather than at their par value as has been traditional with banks. The AICPA's Accounting Research Bulletin No. 43 suggests that capitalization at par value is the accounting treatment preferred by the accounting profession; ${ }^{48}$ this accepted principle attempts to record the substance of the transaction rather than its form. In the discussions on this point in connection with the promulgation of Regulation F, the AICPA represented that their own Accounting Research Bulletin defined the generally accepted accounting principle for such transactions and urged its inclusion in the regulation.

The groups representing the banks were of the opinion that, because of the significance of retained earnings in bank capitalization, the circumstances involved in bank stock dividends differentiated them from those of industry. They proposed that it is in the best interests of the shareholders and therefore incumbent upon bank management to increase the permanent capitalization of the bank as rapidly as possible by the transfer of earnings from undivided profits to the surplus account. Bank surplus, unlike industry surplus, represents relatively permanent capitalization and is the basis for certain legal restrictions placed upon the growth and activities of the bank. If funds are accumulated in the undivided profits account for the payment of a stock dividend, these legal restrictions may prevent a bank from increasing its loan limit, may limit the investment that it can make in banking houses, or may restrict the number of offices that may be established, all of which consequences would be contrary to the best interests of the shareholders. In addition, banks

\footnotetext{
${ }^{47}$ Comptroller of the Currency Reg. $\$$ I8.7(d)(3), 32 Fed. Reg. 7072 (I967).

3 AiCPa, Accounting Research and Terminology Bulletins 59-65 (final ed. ig6r).
} 
have traditionally presented but one surplus account, which may be made up of both paid-in surplus and earned surplus.

Stock dividends of banks may be declared from surplus or from undivided profits. To the extent that they are declared from surplus, they represent only a restatement of permanent capital; shareholder equities are not affected by such a transfer, for each shareholder retains the same interest in the total equities of the corporation.

As a consequence of discussions of this issue and the representations made concerning it, Regulation $\mathrm{F}$ made no change in the historic treatment of stock dividends declared by banks, providing for capitalization at par value. ${ }^{49}$ The Comptroller's new regulations give no guidance at all on the question. In the absence of specific instructions on this particular point, banks are likely to continue the historic practice, followed by other banks, of capitalizing stock dividends at the par value of the shares issued rather than at their fair market value at the time of issue. Comparability within the banking industry is thus not impaired by the difference in regulatory handling of this subject.

\section{E. Disclosure of Market Value of Securities}

During the development of the current regulations, it was advocated by some that banks disclose in their published statements the market value of securities held at the date of the statement. ${ }^{50}$ Bankers in general were opposed to such disclosure, and their position was supported by the FDIC. Banks maintained that this figure represented the situation at a given point in time and was of no continuing significance or benefit. The analysts, on the other hand, contended that only by a disclosure of such current market values could they appraise management's performance in the handling of the security portfolio and develop analyses relative to the yields currently achieved.

Disclosure of market value of the investment portfolio in periods of a depressed securities market could lead to a lack of confidence on the part of depositors, with possibly disastrous effects on the entire banking system. The banks are, of course, under no compulsion to dispose of their securities at the values indicated and may well intend to hold such securities to maturity or for a market rise. The disclosure of existing losses in the portfolio could, however, jeopardize depositor confidence, particularly if such depressed values indicated a substantial impairment of capital.

Following a weighing of the depositor interest against that of the investor and, indeed, the possible effect of such disclosure on the national economy, a current value disclosure requirement was omitted from the Federal Reserve's regulations. In the final analysis, it is believed that little would be gained by the disclosure of such information and that under some circumstances the results could be catastrophic.

\footnotetext{
19 I2 C.F.R. § 206.7I (Supp. I966) (Form F-9C, item Io).

${ }^{50}$ See generally, for earlier advocacy of such disclosure, Hill, Tailoring Banks' Anntal Reports for Both Depositors and Stockholders (pts. I-2), Banking, April 1959, at 40, May 1959, at 54 .
} 


\section{ACHIEVING UNIFoRMity: OUtstanding Issues}

Among the subjects of continuing discussion in bank financial reporting is the possible adoption of the so-called "all-inclusive" income statement. This concept means simply that the income statement should reflect all income and expense items, including even extraordinary, nonrecurring items; the alternative approach reflects the idea that the income statement should reveal current operating performance and that extraordinary items, unrelated to operations for the period, should by-pass the income statement and be directly credited to or charged against the capital accounts. The SEC and the AICPA have tended to favor the all-inclusive income statement, although extraordinary items are expected to be presented "below the line," as additions to or deductions from net operating income in arriving at net income. ${ }^{\text {o1 }}$ In banking, the debate has centered on two important items, the creation of a bad debt reserve and the treatment of gains or losses on securities transactions. There are substantial reasons why the generally preferred all-inclusive income statement would be detrimental to the best interests of banks and investors in bank securities.

Regulation $\mathrm{F}$ did not purport to resolve the debate over the proper function of the income statement. It compromised on the question of presentation, showing first "net operating earnings" and ultimately, after "nonoperating" items, a figure labelled "transferred to undivided profits"; no "net income" figure is shown." More important, Regulation $F$ does not satisfactorily resolve the problems raised by

${ }^{51}$ SEC Accounting Ser. Release No. 70, Dec. 20, 1950; Accounting Principles Bonrd, AICPA, Reporting the Results of Operations (Opinion No. 9, 1966). In its recent opinion the Accounting Principles Board stated " $A$ committee of the [AICPA] is in the process of recommending a format for the income statement of commercial banks. Until such recommendation has been given and until the Board has taken a position thereon, this Opinion is not applicable to commercial banks." Id. at para. 6.

${ }^{52} 12$ C.F.R. $\$ 206.7$ I (Supp. 1966) (Form F-gB). Accountants have been generally critical of the failure to state a net income figure. E.g., Doherty, supra note 37 , at 11,15 . Securities analysts have likewise sought more meaningful income figures. E.g., Cates, supra note 4 , at $14-15$. A recent article, Bank Earnings and the Bottom Line, BANK STock Q., March 1967, at 6, emphasizes the unreliability to investors of the "net operating earnings" figure. The following conclusions, indicating the significance of the so-called "bottom line," are extremely pertinent:

"Last year's bottom line for the 25 -bank group was $\$ 782.9$ million, or 17.8 per cent less than the $\$ 952.2$ million aggregate of earnings reported by the individual banks . . . The difference of \$169.3 million represents \$I2I.5 million net losses taken on sales of securities, \$46.9 million loan charge-offs net of recoveries, and \$o.9 million net sundry debits-all after related taxes . . . .

"Because of the nature of the banking business, one year's results may not be conclusive. Interest earned on loans and investments made today is included in current operating revenues, but losses or gains on these earning assets are not known until later. The bottom line over a period of years provides a more meaningful accounting of the lending, investing, and operating policies of banks.

"In the seven years, 1960-1966 inclusive, net operating earnings of the 25 banks amounted to $\$ 5,468.9$ million. The bottom line, however, totaled $\$ 5,254.4$ million, an attrition of 3.9 per cent. The difference of $\$ 214.5$ million resulted from $\$ 22.9$ million net gains realized on sales of securities, $\$ 230.9$ million net loan losses, and $\$ 6.5$ million other net charges-all after related taxes.

"Net securities gains of \$144.4 million realized in the six years, 1960-1965, were followed by record losses of $\$ 121.5$ million taken in 1966 . It was a 'loss' year for banks." 1d. at 7-8 (italics in original). 
bad debt reserves and securities transactions, assigning both to "below the line" status even though each may have elements of current expense or income. Both issues are thus intertwined with the functional concept of the income statement.

\section{A. Bad Debt Reserves}

While there can be no quarrel with the theory that some charge for possible losses in the loan account should be made against current operating earnings, there have not at the present time been established any criteria for the determination of the proper amount of this charge. Suggestions have been made that the charge to current operating earnings should represent the average loss experience for a five-year period, a ten-year period, or a twenty-year period. Those advocating the five-year period make the point that only by using the most recent data will the content of the loan portfolio approximate the same type of loans as those existing during the current accounting period; thus, the loss ratio encountered during the most recent time interval is that most likely to continue with each successive accounting period. On the other hand, those advocating the longer time interval point out that a five-year span is too short a time to include the effect of the extremes of the economic cycle. In the case of catastrophic losses, such as those resulting from the recent vegetable oil scandal or those of banks participating in a recent substantial credit transaction with a large national industrial company, the five-year average can be substantially distorted. In the case of the loans to the industrial company referred to, recovery was obtained within a five-year period, which would have the effect of minimizing the charge against current operating earnings in those years following the recovery after the charge-off was excluded from the average. It would even be possible under such circumstances for the five-year average to result in a net credit, which on its face would be ridiculous. ${ }^{53}$ For one bank affected by this particular loan, the five-year average ranged from .08 per cent to .0024 per cent as the effect of the recovery was realized.

Another approach advocated by some has been that a determination should be made by management at the end of each accounting period of those loans which represent potential losses and that a charge should be made against current operating earnings in such an amount. Opposing this, of course, is the weight of authority that financial statements should be based upon objective accounting and not upon subjective interpretation. As is pointed out in the AICPA's Accounting Research Bulletin No. 43, "an important objective of income presentation should be the avoidance of any practice that leads to income equalization." 54 Certainly, a sub. jective determination of potential loan losses could easily lead to income equalization.

${ }^{18}$ This could occur where a large recovery was counted in the five-year average but the loss that it related to was not. Sound accounting would not allow this to happen, of course, and would exclude the recovery unless the loss was also included in the average.

it AiCPA, Accounting Resenrch and Terminolocy Bulletins 59 (final ed. $196 \mathrm{r}$ ). 
Under existing Internal Revenue regulations, banks are accorded special treat:ment in the establishment of reserves for bad debts. At the present time, they are permitted to accumulate a reserve for bad debts equal to 2.4 per cent of outstanding loans at the year end, subject to certain exclusions..$^{55}$ This figure can be accumulated over a ten-year period resulting in an allocation each year of .24 per cent, which may be substantially above the actual or average loss experience of a given bank. In the event that the allocation permitted by the Treasury regulations substantially exceeded the actual experience of a given bank, that bank would indeed be reluctant to show as a charge against current operating earnings the maximum provision permitted for tax purposes. On the other hand, not to make a full allocation of the allowable amount with its consequent tax savings would be an act of poor management and would be to the detriment of the investor.

With their year-end statements at December 3r, I965, several banks initiated a policy of including in their operating statement a charge for bad debts. There was no uniformity for the basis of these charges; thus, comparability of the final figure has not been attained. Nonetheless, this is a recognition on the part of these banks that current operating earnings must somehow bear the losses incurred or to be incurred in the loan portfolio. In at least one case, the difference between the charge to current operating earnings and that permitted under the Internal Revenue formula was reported as a charge against undivided profits. Such an approach satisfies the accounting requirement of a charge to operating earnings and at the same time obtains for the bank the maximum tax benefit to be gained under the allowable formula.

It is doubtful that any significant degree of uniformity in the treatment of the bad debt provision will be obtained unless the regulatory authorities set forth regulations governing the point. At the present time, Regulation $\mathrm{F}^{50}$ and the Comptroller's regulation $s^{57}$ provide that the total charge for the bad debt provision will be shown as a "below-the-line" item wholly excluded from the report of net operating earnings. While this approach is not altogether satisfactory, to include the total amount set aside as a charge against earnings under the "all-inclusive" principle would result in an even more substantial distortion of the actual operating profits. Moreover, it would not separate the risk element applicable to the existing loan portfolio from the prudent reservation of a portion of undivided profits in contemplation of potential catastrophic losses which may occur in periods of severe economic depression.

\section{B. Security Transactions}

With respect to the accounting treatment of banks' security gains and losses, the unusual impact of the tax laws again produces artificially wide fluctuations from year

\footnotetext{
${ }^{55}$ Rev. Rul. 65-92, 1965-I Cum. Bull. x12; Rev. Rul. 66-26, 1966-I Cum. Bull. 41.

${ }^{\text {so }}$ I2 C.F.R. $\$ 206.7 \mathrm{I}$ (Supp. I966) (Form F-gB). The bad-debt reserve is to be reconciled in a separate schedule. Id. (Form-9D, Schedule VII).

${ }^{57}$ Comptroller of the Currency Reg. $\$ \$ 18.2(a)-(b), 32$ Fed. Reg. 7071 (1967). A reconcilement of the reserve would appear separately. $\$ 8.6(\mathrm{~b}), 32$ Fed. Reg. 7072 (1967); Appendix D, id. at 7073
} 
to year. If the "all-inclusive" concept were adopted, these fluctuations would destroy comparability between banks and distort year-to-year comparisons of statements of the same bank.

In the treatment of security gains and losses, banks are accorded the usual right under the Internal Revenue Code to claim the capital gains rate on profits on securities held for a period of more than six months. At the same time, they are permitted to deduct losses on securities sold at ordinary tax rates. ${ }^{58}$ However, gains must be offset against losses in a given year, and the tax treatment afforded the remainder will be dictated by whether there is a net gain or a loss. ${ }^{59}$ Under such circumstances, in order to obtain the maximum tax benefit banks must avoid taking security gains and losses in the same year and must strive to concentrate losses in one tax year and gains in another. To include the results of such tax-inspired transactions in the bank's annual report of net operating earnings would thus result in wide distortions and serious misinterpretation.

Past practice in banks' treatment of security gains and losses has included the carrying of the results of such transactions directly to the undivided profits account or to reserves specifically provided for this purpose. If the annual reports did not include a reconciliation of such reserves or of the undivided profits account, the investor or analyst would have no opportunity to ascertain the impact of such transaction on the equity portion of the balance sheet. Under the provisions of Regulation $\mathrm{F}^{80}$ and of the Comptroller's new regulation, ${ }^{61}$ however, the results of such transactions must be shown as a "below-the-line" item. In addition, Regulation $\mathrm{F}^{62}$ and the Comptroller's regulations ${ }^{63}$ each require a reconciliation of the undivided profits account and all reserves, thereby providing further disclosure as to the accumulated results of the investment transactions.

In the event the principle of the "all-inclusive" income statement were adopted, subjective thinking on the part of statement-conscious managements would dictate that gains and losses be taken in a given year to offset the wide fluctuations presently existing. Such a treatment would lose for the bank and for the shareholders the benefits available under the tax laws and would be to their joint detriment. At present, no system has been developed for allocating securities gains or losses among accounting periods in such a way as to avoid the distorting impact of tax-inspired transactions.

\section{ConcLusion}

It will be seen from the above that there are still many variations in the financial reporting of banks and in the philosophies behind such reporting. The most advanced

\footnotetext{
"s INT. Rev. CoDE of $1954, \S 582$ (i).

${ }^{80}$ INT. REv. CODE of I954, \$ I23I(a).

${ }^{00} 12$ C.F.R. $\$ 206.71$ (Supp. I966) (Form F-gB).

${ }^{01}$ Comptroller of the Currency Reg. $\$ 18.5$ (d), 32 Fed. Reg. 707I (1967).

${ }^{02} 12$ C.F.R. $\$ 206.7$ I (Supp. Ig66) (Form F-9C).

${ }^{63}$ Comptroller of the Currency Reg. $\$ 18.6,32$ Fed. Reg. 7071 (1967).
} 
requirement at the present time is represented by Regulation $\mathrm{F}$ of the Federal Reserve Board and its FDIC counterpart. While the recent accounting rules of the Comptroller of the Currency are generally salutary, it is nevertheless to be hoped that the Comptroller will adopt regulations for national banks under his supervision that are substantively identical to Regulation F. The first step toward achieving industrywide accounting uniformity is to achieve uniformity on the part of the supervisory authorities.

Needless to say, such regulatory uniformity would not provide answers to questions relative to the "all-inclusive" income statement, nor would it necessarily comply with the thinking of the financial analysts, the CPAs, and other interested parties. A considerable controversy continues as the AICPA seeks to establish its "generally accepted accounting principles for banks" in certain areas where the accountants' approach differs from the philosophy of a large group of the major banks throughout the country. It would appear, therefore, that the immediate objective is to obtain uniform and comparable reporting on the part of all banks and subsequently to reconcile such reporting practices with the proposals of the financial analysts and the CPAs. Admittedly this will require time, but, with the increasing study currently being devoted to the subject, we can look for continuing progress in this direction. 